\title{
TEKNOLOGI JARINGAN 5G UNTUK JARINGAN MASA DEPAN MENJADI KEBUTUHAN MANUSIA
}

\author{
Patria Adhistian \\ Dosen Teknik Industri Universitas Pamulang \\ dosen01529@unpam.ac.id
}

\begin{abstract}
ABSTRAK
Teknologi broadband seluler terhubung dengan baik dengan kebutuhan manusia akan bertelekomunikasi. Evolusi menuju jaringan masa depan tidak dapat dihindari sejalan dengan tuntutan layanan komunikasi. Jaringan seluler masa depan (5G) akan dipicu oleh populasi manusia yang besar dan tingkat pertumbuhan yang cepat. Keberhasilan teknologi terapan akan diukur oleh literasi internet terhadap populasi manusia. Kriteria yang didorong oleh teknologi untuk jaringan seluler masa depan akan diturunkan berdasarkan keterbatasan teknologi saat ini $(4 \mathrm{G})$ pada perspektif kebutuhan manusia. Breaktrhough akan dibutuhkan untuk mengatasi masalah dalam teknologi saat ini dan akan diklaim sebagai jaringan seluler masa depan $(5 \mathrm{G})$ itu sendiri.
\end{abstract}

Kata Kunci : Ketentuan Indeks - 5G, Broadband Seluler

\section{PENDAHULUAN}

Berdasarkan data bank dunia, pada tahun 2014 populasi dunia telah mencapai 7 miliar, atau sudah dua kali lipat dibandingkan dengan tahun 1960 yang hanya 3 miliar. Dengan adanya angka kelahiran menurut perkiraan yang telah dikampanyekan di seluruh dunia sejak tahun 1980, namun tingkat pertumbuhan populasi saat ini masih $1,16 \%$ per tahun.

Jika laju pertumbuhan populasi ini konstan, kita bisa mengharapkan tambahan 500 juta pada akhir 2020 atau sekitar 10,6 miliar pada akhir tahun 2050. Pemicunya adalah populasi yang semakin meningkat didunia, untuk itu dapat dilihat pada gambar 1.1 Populasi didunia berdasarkan word bank tahun 2019 berikut ini:

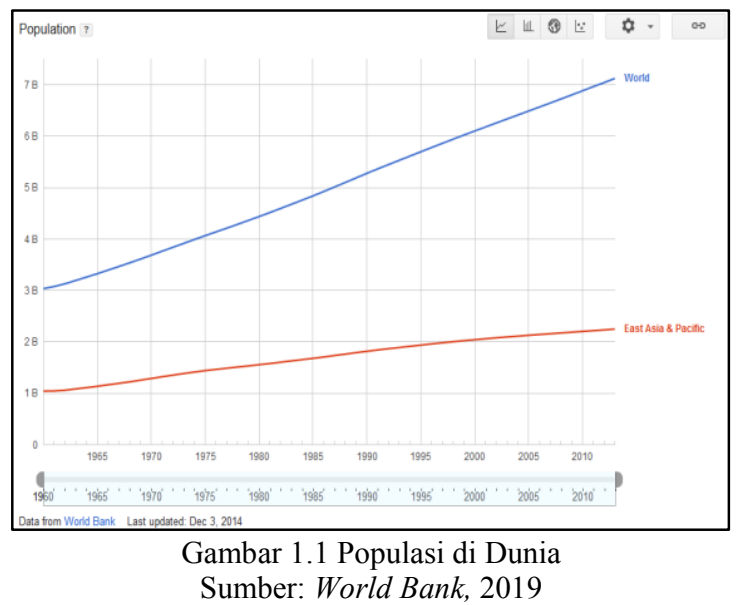

Populasi manusia yang besar akan mendatangkan konsekuensi besar bagi kehidupan. Kebutuhan dasar akan kesehatan, pendidikan, tempat tinggal, air, makanan, bahkan tuntutan pakaian akan meningkat dengan cepat. Salah satu kebutuhan dasar yang juga perlu dipertimbangkan adalah komunikasi.

Telekomunikasi memainkan peran penting dalam kehidupan orang modern. Mereka merasa lebih aman, produktif, inovatif, dan banyak manfaat yang dapat diperoleh dari telekomunikasi, secara spesifik adalah mobile broadband.

ICT (Information and Communication technologies) telah ditetapkan sebagai dasar pembangunan nasional terutama di negaranegara maju dan telah dilakukan di semua negara. Salah satu komponen utama dari infrastruktur ICT adalah teknologi mobile broadband yang meningkatkan cara komunikasi antara orang-orang modern saat ini.

Pemantauan dan pengukuran kinerja fisik sistem TIK sangat penting untuk menilai beban unit pemrosesan komputer (CPU), memori yang tersedia, bandwidth yang digunakan dan sebagainya untuk memastikan bahwa layanan berbasis TIK bekerja dengan benar dalam kaitannya dengan penggunaan yang diharapkan. 


\section{DASAR TEORI}

\section{A. Model Mobile Broadband Population Penetration}

Pengguna Internet telah meningkat pesat sejak perkembangan mobile broadband 2,5 1998 sampai sekarang. Laporan menyatakan bahwa pengguna internet di akhir tahun 2013 adalah $67 \%$ lebih dari 2,8 miliar total pengguna. Seraya program pemerintah dunia untuk meningkatkan angka melek huruf di internet untuk setiap negara, pengembangan teknologi seluler broadband telah menjadi tantangan pada abad ke-21, (Word Bank, 2019). Berikut adalah gambar 1.2 Mobile Broadband Population Penetration:

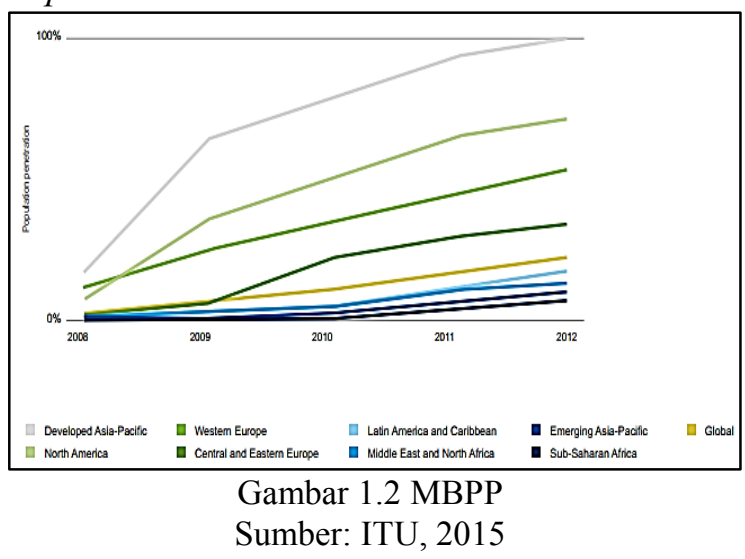

Seperti dalam masyarakat modern kita tahu bahwa komunikasi digital telah didorong oleh ekonomi untuk tumbuh lebih cepat dan membawa banyak peluang. Pasar dapat diperdagangkan secara global menggunakan toko online. Perubahan Data dapat diperdagangkan lebih cepat dengan jarak jauh, memungkinkan bisnis untuk memiliki perwakilan di daerah terpencil.

Menurut prediksi dan analisis statistik dari Internasional Telecommunication Union (ITU, 2015), diperkirakan akan meningkatkan penggunaan nirkabel dan seluler 1.000 kali lipat antara 2010 sampai 2025, dengan pertumbuhan 10-100 kali dalam periode dari 2020 hingga 2030. Dengan pertumbuhan data seluler yang eksponensial ini, berbagai solusi diperlukan untuk memenuhi secara terus menerus meningkatnya jaringan seluler saat ini. Dengan evolusi ke LTE dan 5G, jaringan seluler telah berkembang sebagai jaringan multi-tier yang terdiri dari jaringan konvensional jaringan seluler (mis., jaringan makrosel) dengan multiple low power base station (mis., smallcell) (Wang, L.; Wang, Y.; Ding, Z.; Wang, X, 2015).

Penggunaan smallcell dalam jaringan heterogen semacam itu (HetNets), termasuk picocells dan femtocells overlay pada jaringan macrocell adalah salah satu teknik yang menjanjikan untuk memenuhi semakin meningkat permintaan besar untuk data nirkabel di masa depan. Di sisi lain, banyak penelitian memperhatikan efisiensi energi dalam jaringan smallcells yang padat. Sebuah pendekatan baru untuk mengkontrol power energi dan penjadwalan users yang digunakan untuk mengoptimalkan efisiensi energi dalam hal bits per unit konsumsi energi dalam jaringan Ultra-Dense Smallcels (UDNs). (Zhu Xiao, Hongjing Liu, Vincent Havyarimana, Tong Li, Dong Wang, 2016)

\section{B. Pemodelan Jaringan Heterogen Networks}

Menurut (Ghosh A, 2012), model ringkas dimulai dengan proses titik spasial hingga secara statistik memodelkan lokasi base station di HetNets. Proses titik yang paling sederhana dan paling dikenal, yaitu Poisson Process Point (PPP), mengasumsikan bahwa base station di masing-masing smallcells secara independen dan didistribusikan dengan kepadatan $(\lambda s)$. Dalam penelitian ini, kami mempertimbangkan jaringan heterogen multitier yang terdiri macrocells dan dua jenis microcells, picocell dan femtocell, yang merupakan bagian dari pico-tier dan femtotier, masing-masing. Picocell base station (PBSs) digunakan untuk meningkatkan jangkauan macrocell untuk jangkauan luas yang radius jangkauannya dilambangkan $\mathrm{Rp}$. Femtocell base station (FBSs) digunakan untuk rumah, kantor dan area pribadi lain yang membutuhkan kecepatan data yang tinggi. Untuk (Rf) menunjukkan radius jangkauan FBS dan sehingga $\mathrm{Rp}>\mathrm{Rf}$. Oleh karena itu, di pico-tier, kita dapat mengasumsikan distribusi penyebaran PBS berikut PPP kepadatan $\lambda \mathrm{p}$. Distribusi pengguna picocell mengikuti PPP dengan kepadatan $\mu \mathrm{p}$. Untuk mendapatkan link kualitas yang bagus, setiap pengguna picocell mengakses PBS yang dilayani oleh base station terdekat. Jarak antara picocell dan base station dinyatakan sebagai rp.

$$
\text { fpico (rp) }=2 \pi \lambda p \operatorname{rp} \exp \left(-\lambda p \pi \mathrm{rp}^{2}\right)
$$




\section{METODE DAN TEKNIK PENGUKURAN}

Penelitian ini dilakukan dengan menggunakan metode kualitatif yang berdasar pada data-data yang diambil secara purposive. Mengacu pada kebutuhan manusia terhadap evolusi teknologi broadband telah bertentangan dengan beberapa parameter diantaranya adalah

\section{A. User Capacity}

Terobosan ponsel broadband sejak 2,5 G dibatasi oleh kapasitas pengguna dari setiap teknologi itu sendiri. 3,5 HSPA dapat menampung hingga 128 users/cell (DL) dan 60 users/sel (UL), sedangkan 4G LTE hingga 420 users/cell.

\section{B. Users Experience}

Melalui teknologi broadband $4 \mathrm{G}$ saat ini yang dapat mencapai $>1$ Gbps menggunakan antena MIMO order yang lebih tinggi dan agregasi pembawa Bandwith.

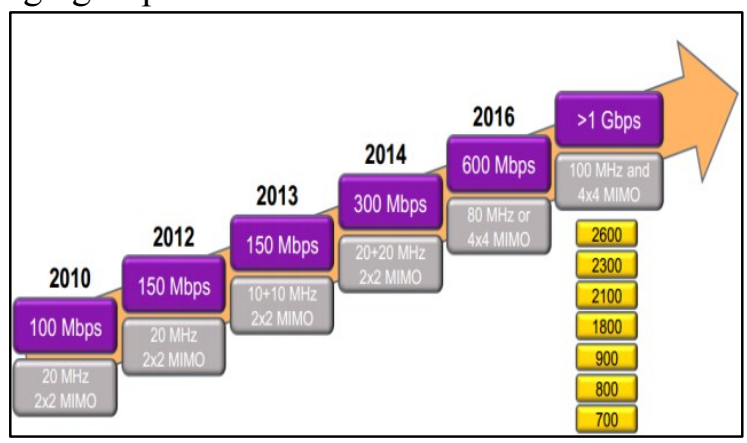

Gambar 2.1 LTE Cell Troughput

Capabilities

Tantangannya adalah karena ketersediaan bandwith yang tepat untuk memenuhi kapasitas ini yang perlu diperhitungkan. Dan juga peraturan pemerintah merupakan suatu kendala.

\section{Evolving Infrastructure Low Cost Deployment}

Pertumbuhan teknologi tidak selalu sejalan dengan model bisnis dalam hal investasi. Teknologi dengan investasi besar dan profitabilitas rendah mungkin tidak menjadi tren dan pembangunan lambat.

Dengan 4G LTE saat ini menawarkan kecepatan atas semua jaringan IP, yang datang ke investasi besar dari perspektif operator. Dalam perspektif transportasi, banyak operator di dunia yang masih menggunakan jaringan hibrida.

Untuk tulang punggung, dan gelombang mikro dari BTS ke tulang belakang atau HUB site. Pengembangan transportasi ke semua FO akan menjadi tantangan besar yang tidak hanya terkait dengan sektor swasta tetapi juga pemerintah untuk membangun infrastruktur yang besar ini.

\section{HASIL DAN PEMBAHASAN}

Untuk mendorong mengakomodasi titik kunci, beberapa daerah perlu ditingkatkan atau diganti untuk membawa kemampuan yang lebih besar.

\section{A. Alokasi Spectrum.}

Jaringan seluler masa depan mungkin tidak dapat menghindari pertanyaan tentang frekuensi dan bandwith alokasi agar teknologi baru ini dapat digunakan. Selalu ada 2 pilihan, pertama untuk menggunakan alokasi frekuensi saat ini yang mengurangi kapasitas teknologi saat ini adalah $(2 \mathrm{G}, 3 \mathrm{G}, \& 4 \mathrm{G})$.

Kedua untuk menemukan spektrum baru masih sulit menemukan letak lokasi untuk teknologi baru untuk mengambil tempat. Sementara itu dalam pengelolaan dalam alokasi frekwensi jaringan pada penetapan spektrum perencanaanya sesuai dengan bebrapa frekwensi (specturm engineering), pengendalian, dan manajemen interferensinya.

Didalam proposal dari ilmuwan rusia, new spectrum, telah diterbitkan dan dikategorikan dalam Priorization Of Frequency Bands In The Range 40,5 - 95,0 GHz. Dapat dilihat tabel di bawah ini.

Tabel 3.1 Priorization Of Frequency Bands In The Range 40,5 - 95,0 GHz.

\begin{tabular}{|l|l|l|}
\hline $\begin{array}{l}\text { Frequency } \\
\text { Band, GHz }\end{array}$ & $\begin{array}{l}\text { Bandwith, } \\
\text { GHz }\end{array}$ & Priority \\
\hline $40.5-42.5$ & 2 & Medium \\
\hline $42.5-43.5$ & 1 & High \\
\hline $43.5-45.5$ & 2 & Low \\
\hline $45.5-47.0$ & 1.5 & High \\
\hline $47.2-50.2$ & 3 & High \\
\hline $50.4-52.6$ & 2.2 & Medium-low \\
\hline $55.78-57,0$ & 1.22 & High \\
1.22 High & 7 & High \\
\hline $57-66$ & 5 & High \\
\hline $66-71$ & 5 & High \\
\hline $71-76$ & 5 & High \\
\hline $81-86$ & & \\
\hline
\end{tabular}




\section{B. Densifikasi Jaringan}

Tantangan besar dari jaringan seluler masa depan adalah hetnet, PicoCell dan manajemen relay. Lebih tinggi urutan frekuensi pembawa dan kapasitas dibutuhkan picocell besar untuk meningkatkan pengguna melalui put. Penghentian interferensi UL [7] akan menjadi titik kunci untuk memungkinkan penyebaran jaringan cepat $5 \mathrm{G}$.

\section{Modulasi Carrier}

Salah satu ide untuk terobosan yang diteliti oleh ilmuwan korea adalah Beam Division Multiple Access (BDMA). Untuk meningkatkan kualitas SNR dan sinyal serta efisiensi pembawa, antena pintar berdasarkan antena array bertahap. Modulasi Carrier pada 5G masih dipertanyakan sebagai perintah tertinggi saat ini QAM (128/256) masih tidak cocok untuk kemampuan UE karena masalah penggunaan daya. Terobosan baru mungkin diperlukan untuk meningkatkan efisiensi spektral bit dari teknologi modulasi pembawa.

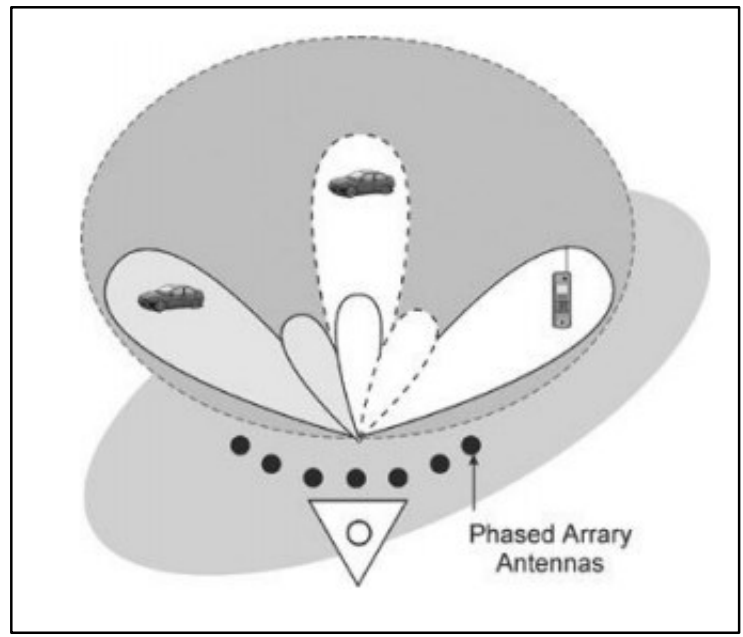

Gambar 4.1 Beam Division Multiple Access Sumber : Pankaj Kumar Dalela dkk, 2018

\section{Arsitektur Jaringan}

Semua IPv6 harus dapat mencapai kapasitas yang lebih besar dan mengurangi layer 2 latensi dalam jaringan 5G. Salah satu tujuan untuk meningkatkan kinerja inti adalah menambahkan awan di saat ini 4G EPC [4]. Membentuk awan EPC yang tersebar, meningkatkan kinerja dan mengurangi latensi, menggabungkan pemrosesan atau distribusi paralel ke dalam hitungan. Lebih jelasnya dapat dilihat pada gambar 4.2 dibawah ini:

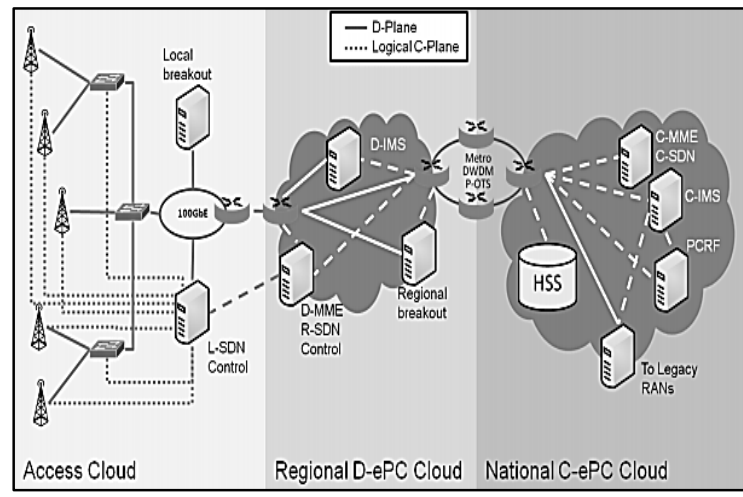

Gambar 4.2 Proposed Architecture for the $5 G$ EPC Network

\section{E. Jaringan Management Kognitif}

Meningkatkan IOT akan menjadi fitur kunci dalam menyebarkan jaringan 5G. 4G COMP saat ini (koordinasi multi-point) akan menjadi terobosan awal seperti dalam jaringan kognitif. Setiap NE akan memerlukan koordinasi untuk parameter yang diperlukan seperti gangguan, alokasi sumber daya dan jabat tangan antara terminal nirkable.

\section{KESIMPULAN}

Dalam penelitian ini dapat disimpulkan sebagai berikut :

1. Keberhasilan teknologi terapan akan diukur oleh literasi internet terhadap populasi manusia. Kriteria yang didorong oleh teknologi untuk jaringan seluler masa depan akan diturunkan berdasarkan keterbatasan teknologi saat ini (4G) pada perspektif kebutuhan manusia. Breaktrhough akan dibutuhkan untuk mengatasi masalah dalam teknologi saat ini dan akan diklaim sebagai jaringan seluler masa depan (5G) itu sendiri.

2. Kesempatan untuk peluang industri dengan teknologi $5 \mathrm{G}$ dapat dilaksanakan dengan mempersipkan beberapa riset yang menjadi sorotan forum internasional, dan pada jaringan heterogen dimana akan menbutuhkan beberapa femtocell yang bersifat antara keterkaitan dengan keamanan pada jaringan $5 \mathrm{G}$. 


\section{DAFTAR PUSTAKA}

A.F. Cattoni, P.E. Mogensen, S. Vesterinen, M. Laitila, L. Schumacher, P. Ameigeiras, "Ethernet-Based Mobility Architecture for 5G", Department of Electronic Systems, Aalborg University.

Boccardi F, dkk, 2014, “ Five Disruptive Technology Directions For 5G. IEEE Comunication Magazine", http://doi.org/10.1109/MCOM.2014.673 6746.

Brown, Kathy. (2019, December 15). http://www.internetsociety.org/sites/defa ult/files/Global Internet Report_2014_0 .pdf

Ericsson AB. (2015). "5G Energy Performance Network Energy”.

Ghosh, A.; Mangalvedhe, N.; Ratasuk, R.; Mondal, B.; Cudak, M.; Visotsky, E.; Thomas, T.A.; Andrews, J.G.; Ping, X.; Han, S.J.; et al. Heterogeneous cellular networks: From theory to practice. IEEE Commun. Mag. 2012, 50, 54-64

Grigory Bochechka, Valery Tikhvinskiy, "Spectrum Occupation and Perspectives Millimeter for 5G Networks", Moscow, Russia, g.bochechka@icominvest.ru, v.tikhvinskiy@icominvest.ru.

International Telecommunication Union. IMT Traffic Estimates for the Years 2020 to 2030; Report ITU-R M.2370-0 (07/2015); ITU Publications: Geneva, Switzerland, 2015.

Naga Bhushan, Junyi Li, Durga Malladi, Rob Gilmore, Dean Brenner, Aleksandar Damnjanovic, Ravi Teja, Sukhavasi, Chirag Patel, and Stefan Geirhofer, "Network Densification: The Dominant Theme for Wireless Evolution into 5G", Qualcomm Technologies, Incorporated

Pankaj Kumar Dalela, Pramod Bhave, Phuspender Yadav, Anshul Yadave, Vipin Tyagi, 2018 "Beam Division Multiple Access (BDMA) and modulation formats for 5G: Heir of OFDM?", IEEE Xplore.
Samarakoon, S.; Bennis, M.; Saad, W.; Debbah, M.; Latva-aho, M. Ultra dense small cell networks: Turning density into energy efficiency. IEEE J. Sel. Areas Commun. 2016, 34, 1267-1280.

Sandhu, Sukhpreet. "Nokia LTE eNodeB Solutions", Nokia Network, Incorporated.

World bank. (2019, November 28). http://www.google.com/publicdata/expl ore?ds=d5bncppjof8f9_\&met_y=sp_pop - totl\&hl=en\&dl=en

Warren, D., \& Dewar, C. (2014). Understanding 5G: Perspectives on future technological advancements in mobile. London.

Wang, L.; Wang, Y.; Ding, Z.; Wang, X. Cell Selection Game for Densely-Deployed Sensor and Mobile Devices in 5G Networks Integrating Heterogeneous Cells and the Internet of Things. Sensors (2015), 15, 24230 24256.

Zhu Xiao, Hongjing Liu, Vincent Havyarimana, Tong Li, Dong Wang (2016), Analytical Study on Multi-Tier 5G Heterogeneous Small Cell Networks: Coverage Performance and Energy Efficiency, Sensors 2016, 16(11), 1854 